\title{
アスペクト比の異なる部分支持された薄鋼板のせん断座屈耐力 及び座屈後耐力評価 \\ BUCKLING STRENGTH AND POST-BUCKLING STRENGTH OF THIN STEEL PLATE WITH VARIOUS ASPECT RATIO SUPPORTED PARTIALLY BY STEEL FRAMES
}

\author{
金箱温 春*1, 小河利 行*2, 竹内 徹*3, 松原洋 介*1 \\ Yoshiharu KANEBAKO, Toshiyuki OGAWA, Toru TAKEUCHI \\ and Yousuke MATSUBARA
}

\begin{abstract}
The authors described buckling strength and post buckling strength of thin steel plate with aspect ratio of 1.0 partially supported by steel frames in the previous paper. In this paper, the buckling stress of the plate of aspect ratio between 1.0 and 3.0 used by the bracing model is discussed. The approximation formula of the buckling strength is proposed by using the tensilecompressive bracing model. The result are compared with the buckling mode analysis and the geometric nonlinear analysis by FEM. The approximation formula of the post buckling strength of thin steel plate combined with steel stiff frame is proposed in consideration of stress distribution and yield condition. Also the relatinship between the bending rigidity of the steel flame and post buckling strength of the steel plate is examined.
\end{abstract}

\section{Keywords : Thin Steel Plate, Partially Support, Shear Buckling, Post-Buckling Strength, FEM Analysis, Bracing Model, Aspect Ratio}

薄鋼板, 部分支持, せん断座屈, 座屈後耐力, FEM解析, ブレースモデル, アスペクト比

\section{1.はじめに}

前報において，筆者らはアスペクト比1.0の形状の薄鋼板を対象とし て, 部分支持された状態でせん断力を受ける場合の座屈耐力及び座屈 後耐力の評価式の提案をブレースモデルに基づいて行い, 数值解析結 果と合わせて示している1)。その結果, ブレースモデル及び最大耐力時の 応力分布に基づいた提案式により，枠材剛性がゼロの場合，及び枠材剛性 が十分に大きい場合については簡便な式で座屈耐力, 座屈後最大耐力 が評価できることを示した。

鋼板と周囲の枠材が連続的に接合された状態では, 既往の研究にお いてアスペクト比の影響を考虑したせん断座屈強度の評価が行なわれ ており, 周辺単純支持及び周辺固定支持の座屈耐力の算定式において 座屈係数として考虑されている ${ }^{12}$ 。実際には単純支持と固定支持の中 間の状態も想定され, Leeにより中間状態での座屈係数についてアス ペクト比をパラメータとして提案されている220Aliniaは鋼板せん断壁 を対象とした数值解析により,座屈耐力に対しては枠材の㨭れ剛性の 影響により座屈耐力が変わることを示し,アスペクト比の影響を座屈 倸数で表している3)。一方, 座屈後耐力に対するアスペクト比の影響に 関する研究として, 見村, 秋山は幅厚比が $260 \sim 460$ でアスペクト比 が1.0から 2.0 の鋼板耐震壁の繰り返し加力実験により復元力特性の考 察を行ない,最大耐力に関しては完全張力場理論による張力場の形成 する角度としてアスペクト比の影響を評価している4)。Driver ${ }^{5), 6)}$, Elgaaly ${ }^{7}$ はストライプ状ブレースのモデルを用いて座屈後挙動の予測 を行ない実験結果との対応を検討しているが, アスペクト比をパラ メータとした検討は行なっていない。山梶は格子型ブレースのモデル
を用いて正方形, 縦長, 横長のフレ゙ーム付き鋼板の数値解析を行い, フ レーム及び鋼板の忘力分布や復元力特性を明らかにしているが,アス ペクト比をパラメータとする評価式は採用していない8) 析結果をもとに, アスペクト比の影響を座屈保数によって考慮し, 弾 性座屈耐力と塑性せん断耐力によってプレートガーダーの座屈後耐力 評価を行なっている9。木村, 小河は, 座屈後耐力に対してもアスペク 卜比の影響を座屈係数として考虑することで評価できることを示し， また周辺のリブ岡性と座屈後耐力の関係をアスペクト比 1.0 の場合につ いて検討している ${ }^{10), 11)}$ 。以上のように, 座屈後耐力や座屈後挙動に関 してさまざまな研究が行なわれているが,アスペクト比の影響につい て座屈耐力のように統一的に確立されたものはない。

本論文は, 前報の考え方を拡張し, 1から3までのアスペクト比の範 囲で, せん断力を受ける部分支持された薄板鋼板のせん断座屈耐力及 び座屈後耐力の評価式を提案するものである。座屈後而力は枠材剛性 がゼロの場合と十分に大きい場合について検討し，さらに枠材の曲げ 剛性が銅板の座屈後耐力に及ぼす影響を検討する。

\section{2. 部分支持された板の座届耐力}

\section{2-1. ブレースモデルによる座屈耐力の推定式}

本論の数値解析は前報同様, 有限要素法の汎用プログラムMIDAS/GEN (ver. 7.0.0) を用いて行い, 弾性応力解析, 座屈固有值解析, 複合非線 形解析の 3 種類の解析を行っている ${ }^{13)}$ 。板要素は四角形要素で, 非適 合モードを有するアイソパラメトリック要素を用いている。解析モデ ルは図1に示すようにアスペクト比 $\beta$ ( $\beta$ は1.0,2.0,3.0を検討)の板
$* 1$ 金箱構造設計事務所 工修

*2 東京工業大学理工学研究科建築学専攻 教授. 工博

*3 東京工業大学理工学研究科建築学専攻 准教授・博士 (工学) 
要素モデルで短辺方向の一辺を20分割の正方形要素を用いている。支 持部分では鋼板の面外方向の並進と回転を拘束し, また, 枠材どうし は剛体連結機能を用いて枠材間の距離が変わらないようモデル化して いる。さらに, 板が動かないように下部の 2 頂点をピンとピンロー ラーで支持している。荷重は板に純せん断が加わるように支持区間内 に載荷している。

図 2 に $\alpha=0.2, \beta=2.0$ の場合の解析結果より得られた弾性応力度 分布 (主応力方向とその大きさ)を示している。前報と同様の仮定条 件を適用し，鋼板を対角線方向の圧縮ブレースと引張ブレースとして モデル化し，圧縮ブレース側の座屈時点を板のせん断座屈と考えて $\alpha$ および $\beta$ との関係において座屈耐力の推定式を導く。

図2では対角線方向に引張, 压縮主応力が支持部から中央にかけて 広がりを持っている。対角線方向の引張, 圧縮主応力が支持部から中 央にかけての広がりの角度を $3: 1$ と仮定,ブレースは支持部から中央 に広がりを持つものとする。図中aはブレース中央部の有効幅の半分 を, bは隅角部での応力伝達幅を示す。AからDまでの各部の長さは幾 何学的に以下となる。

$$
\begin{aligned}
& \theta=\tan ^{-1} \frac{1}{\beta} \\
& A=\frac{\alpha \cdot \beta \cdot L}{\sqrt{1+\beta^{2}}} \\
& B=\frac{\alpha \cdot \beta^{2} \cdot L}{\sqrt{1+\beta^{2}}} \\
& C=\frac{\sqrt{1+\beta^{2}}}{2} \cdot L-\frac{\alpha \cdot \beta^{2}}{\sqrt{1+\beta^{2}}} \cdot L \\
& D=C-A \cdot \tan \theta=\left(\frac{1}{2}-\alpha\right) \cdot \sqrt{1+\beta^{2}} \cdot L
\end{aligned}
$$

これらの値を用いて, 図中の $\mathrm{a}$ と b以以下となる。

$$
\begin{aligned}
& a=A+\frac{1}{3} \cdot D=\frac{1}{\sqrt{1+\beta^{2}}}\left\{\alpha \cdot \beta+\left(\frac{1}{2}-\alpha\right) \cdot \frac{\left(1+\beta^{2}\right)}{3}\right\} \cdot L \\
& b=\frac{\alpha \cdot \beta \cdot L}{\sqrt{1+\beta^{2}}}
\end{aligned}
$$

中央に広がったブレース断面を幅2aの長方形断面とみなすとこの部分

の断面 2 次モーメントは以下となる。

$$
\begin{aligned}
I= & \frac{1}{12} \cdot 2 a \cdot t^{3}=\frac{1}{6}\left\{\frac{\alpha \beta}{\sqrt{1+\beta^{2}}}+\left(\frac{1}{2}-\alpha\right) \cdot \frac{\sqrt{1+\beta^{2}}}{3}\right\} L t^{3} \\
& t: \text { 鋼板の板厚 }, L: \text { 短辺の辺長 }
\end{aligned}
$$

座屈長さ $\ell_{k}$ は図3に示す $\ell$ の0.7倍とする。

$$
\begin{aligned}
& l=(B+C)-\frac{\alpha \cdot \beta \cdot L}{2} \cdot \frac{1}{\cos \theta}=\frac{(1-\alpha)}{2} \cdot \sqrt{1+\beta^{2}} \cdot L \\
& l_{k}=0.7 \cdot l=0.35(1-\alpha) \cdot \sqrt{1+\beta^{2}}
\end{aligned}
$$

以上より, 図3に示す圧縮ブレースの座屈荷重は以下の式で表せる。

$$
\left(P_{c r}\right)_{c 1}=\frac{\pi^{2} E I}{l_{k}^{2}}=\frac{\pi^{2} E}{0.735} \cdot \frac{\left\{\frac{\alpha \cdot \beta}{\sqrt{1+\beta^{2}}}+\left(\frac{1}{2}-\alpha\right) \frac{\sqrt{1+\beta^{2}}}{3}\right\}}{(1-\alpha)^{2} \cdot\left(1+\beta^{2}\right)} \cdot\left(\frac{t}{L}\right)^{2} \cdot L \cdot t
$$

\section{$E$ ：鋼材のヤング倸数}

一方, 図2の応力分布を見ると,隅角部では対角線方向と直交方向にも 応力が発生し, 左下, 右上部分では圧縮力が支持点間で生じている。 $\alpha$ の異なる場合においてもこの部分の态力度は中央部とほぼ同じである傾 向が確認されたため, 隅角部の圧縮応力は中央部と同じであると仮定す る。2bの部分での負担する力を $\left(P_{c r}\right)_{c 2}$ とすれば, 圧縮ゾーンの全体とし ての軸力は,

$$
\begin{aligned}
& \left(P_{c r}\right)_{c 1}+\left(P_{c r}\right)_{c 2}=\left(P_{c r}\right)_{c 1}\left(1+\frac{b}{a}\right) \\
こ こ て ゙ \quad & \frac{b}{a}=\frac{\alpha \beta}{\alpha \beta+\left(\frac{1}{2}-\alpha\right) \cdot \frac{\left(1+\beta^{2}\right)}{3}}
\end{aligned}
$$

である。このとき引張ブレースも同等の力を負担していることより,板 の座屈耐力 $Q_{c r}$ は以下となる。

$$
\begin{aligned}
Q_{c r} & =\frac{2}{\sqrt{1+\beta^{2}}}\left(P_{c r}\right)_{c 1} \cdot\left(1+\frac{b}{a}\right) \\
& =2.722 \pi^{2} \cdot E \cdot \frac{12 \alpha \cdot \beta+(1-2 \alpha)\left(1+\beta^{2}\right)}{6(1-\alpha)^{2}\left(1+\beta^{2}\right)^{2}} \cdot \frac{L \cdot t}{\lambda^{2}}
\end{aligned}
$$

\section{$\lambda:$ 鋼板の幅厚比 $L / t$}

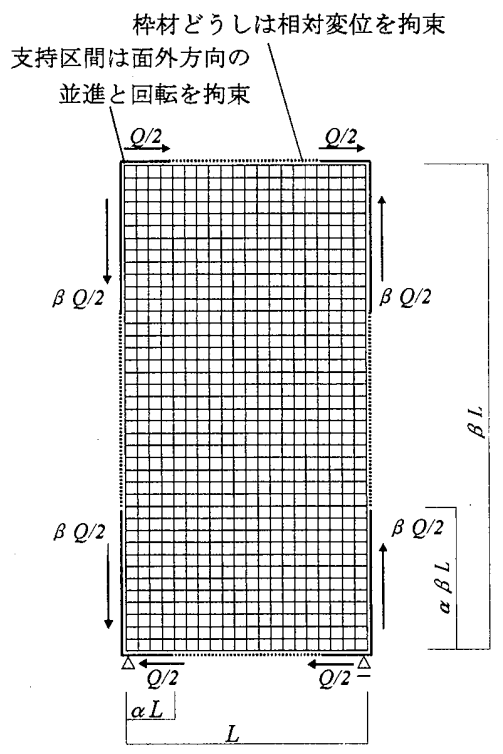

図 1 弾性応力解析モデル

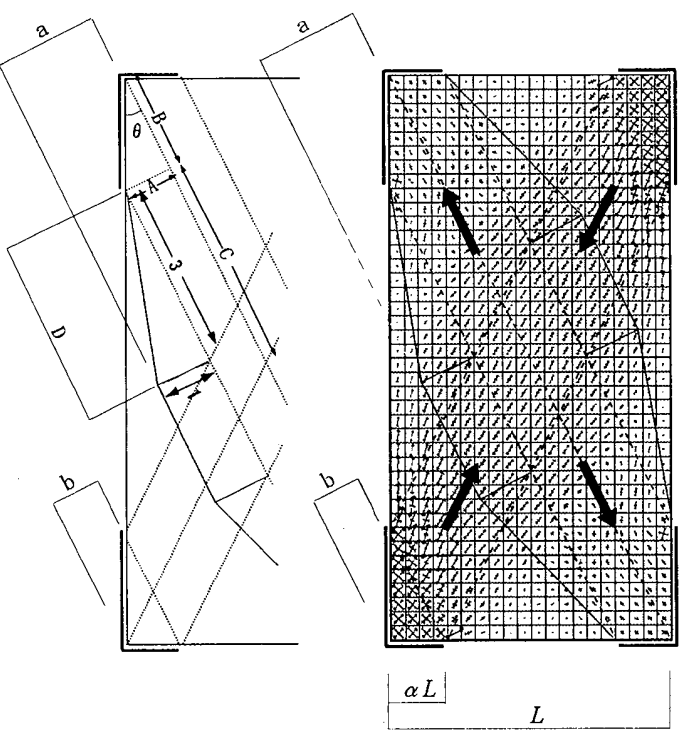

図 2 部分支持された板の忘力状態とブレースモデル

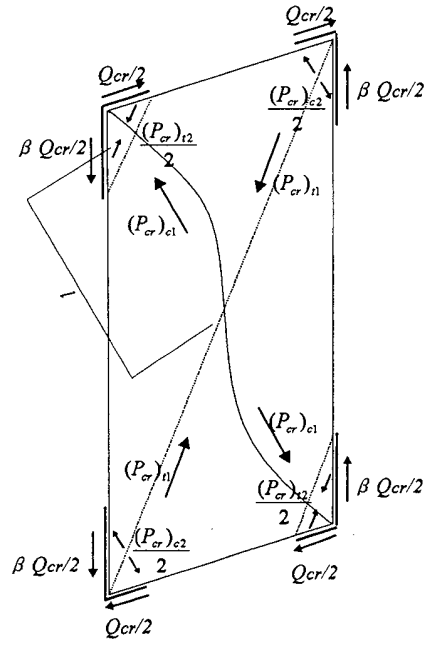

図 3 力の釣り合いと圧縮ブレースの 座屈長さの取り方 


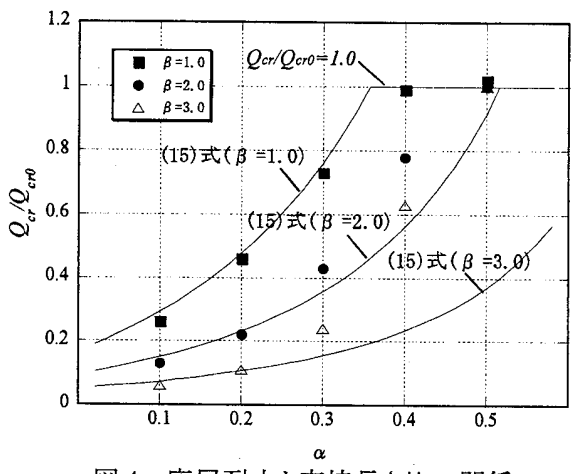

図 4 座屈耐力と支持長さ比の関倸

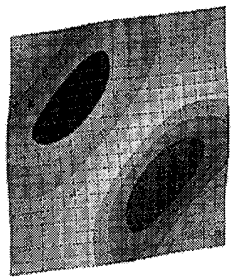

(a) $\alpha=0.2, \beta=1.0$

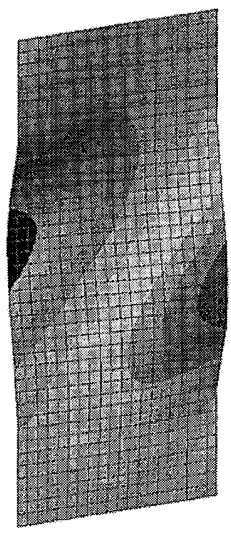

(b) $\alpha=0.2, \beta=2.0$

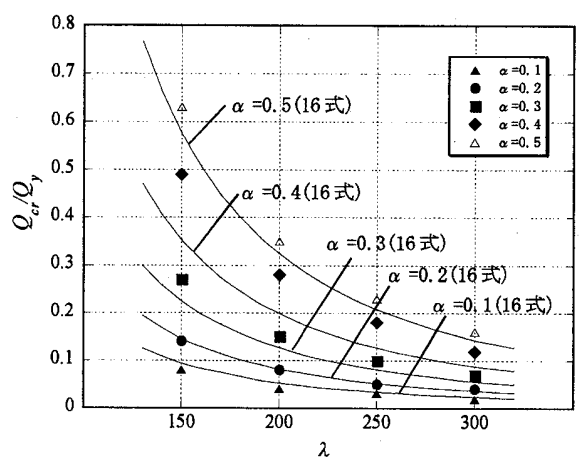

図 5(a) 座屈耐力と幅厚比の関係 $(\beta=2.0)$

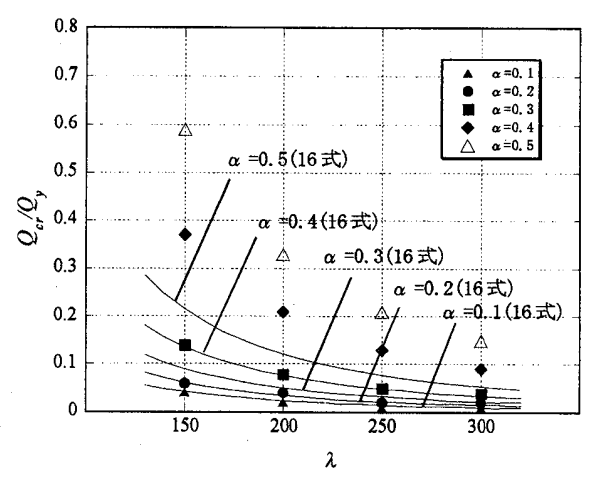

図 5(b) 座屈耐力と幅厚比の関係 $(\beta=3.0)$

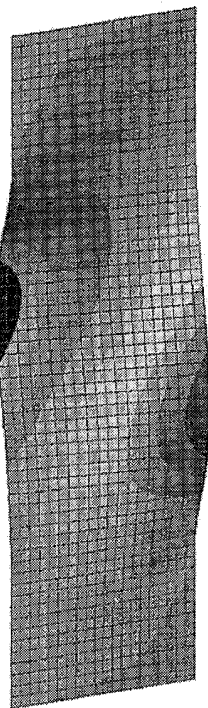

(c) $\alpha=0.2, \beta=3.0$

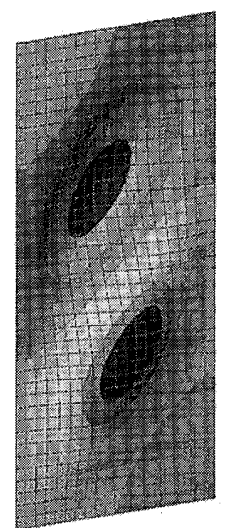

(d) $\alpha=0.5 \quad \beta=2.0$

図 6 座屈モード $(\lambda=250$ の場合 $)$

ここで, 四周固定のせん断板の座屈理論式は下式で与えられる ${ }^{12)}$ 。

$$
Q_{c r 0}=\left(\frac{5.6}{\beta^{2}}+8.98\right) \frac{E \cdot \pi^{2}}{10.92} \cdot \frac{L \cdot t}{\lambda^{2}}
$$

これを用いて (13)式を無次元化すると下式となる。

$$
\frac{Q_{c r}}{Q_{c r 0}}=4.92 \cdot \frac{12 \alpha \cdot \beta+(1-2 \alpha) \cdot\left(1+\beta^{2}\right)}{\left\{(1-\alpha)^{2} \cdot\left(1+\beta^{2}\right)^{2}\right\} \cdot\left(\frac{5.6}{\beta^{2}}+8.98\right)}
$$

（15）式は幅厚比に依存せず， $\alpha$ と $\beta$ だけの関数として表され，図4の 実線及び破線で示すものとなる。後述する座屈後耐力との統一を計る ため(14)式をQyで無次元化すると以下となる。

$$
\begin{aligned}
\frac{Q_{c r}}{Q_{y}} & =\frac{0.785 \pi^{2} \cdot E}{\sigma_{y} \cdot \lambda^{2}} \cdot \frac{12 \alpha \cdot \beta+(1-2 \alpha) \cdot\left(1+\beta^{2}\right)}{(1-\alpha)^{2} \cdot\left(1+\beta^{2}\right)^{2}} \\
\sigma_{y}: & \text { 降伏応力度 }
\end{aligned}
$$

(15)，(16)式とも $\beta=1.0$ とすると文献1)で示した式と同じになる。

\section{2-2. 座屈固有值解析}

座屈固有值解析を行い,2-1. で検討をした周辺を部分支持された板 の座屈耐力を求める。パラメータは周辺の支持長さ $\alpha$ と幅厚比とする。 $\alpha$ は $0.1,0.2,0.3,0.4,0.5$ の 5 種類（ $\alpha=0.5$ は全周支持）とし, 幅 厚比は $150,200,250,300$ の 4 種類, アスペクト比は1.0,2.0,3.0の 3 種類とする。解析モデルの設定は前項の弹性応力解析と同様, 図 1 に

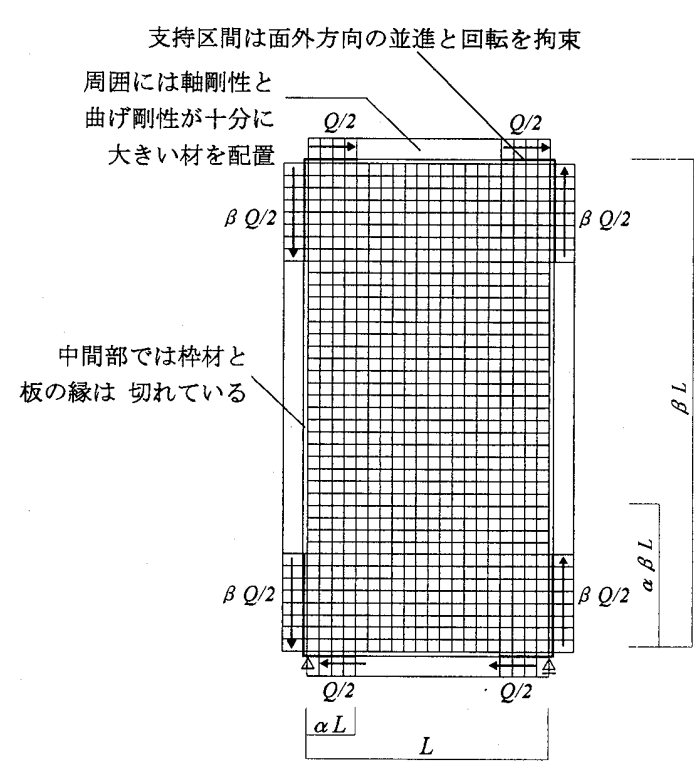

図 7 枠材付き鋼板の解析モデル

示すものを用いた。

図4は板周辺の支持長さ比 $\alpha$ と四周支持の板のせん断座屈耐力で無 次元化した $Q_{c r}$ の関係を固有值解析結果と (15) 式とを合わせて示したも のである。全周固定の座屈耐力 $Q_{\text {cro }}$ に対する座屈耐力の比は板の幅厚 比に関係なく $\alpha$ と $\beta$ のみに依存した值となっている。図 4 に示される ように, $\beta$ が1.0の場合に $\alpha$ が大きくなると(15)式は1.0を超えるが, この場合は座屈耐力は (14)式で表されるものと考えられる。 $\beta$ が2. 0 や3.0で $\alpha$ が0.3を超える場合には, 提案式と数值解析結果の乘離が大

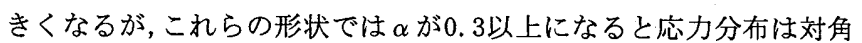
線方向から 45 度方向になる傾向があるため, 提案式のモデル化との相 違が生じてくることが理由である。

図5に板の降伏せん断力 $Q_{y}$ で無次元化した $Q_{c r} / Q_{y}$ を, 2-1. で求めた （16）式とともに示す。SS400級の板を想定し, 降伏応力度 $235 \mathrm{~N} / \mathrm{mm}^{2}$ と した。幅厚比が大きく,また $\alpha$ が小さくなるほど板の座屈耐力が小さ

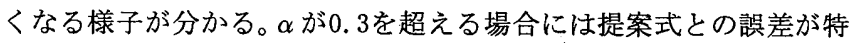
に大きくなるため, 次項以降でブレースモデルによる評価式を用いて 座屈後耐力評価を行な際には, $\alpha$ が0.3程度以下での適用することを 前提とする。この適用範囲ではアスペクト比に拘わらず(15)式の值は 1.0を下回り,この式のみで座屈耐力は表記できる。

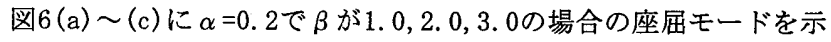
す。いずれも座屈モードは引張力が生じる対角線上に不動域が分布し, 圧縮力が生じる対角線方向に2波の変形を生じるモードであり，ほぼ 


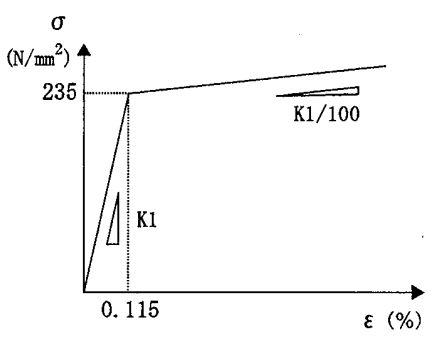

図 8 材料の応力ー歪み関倸

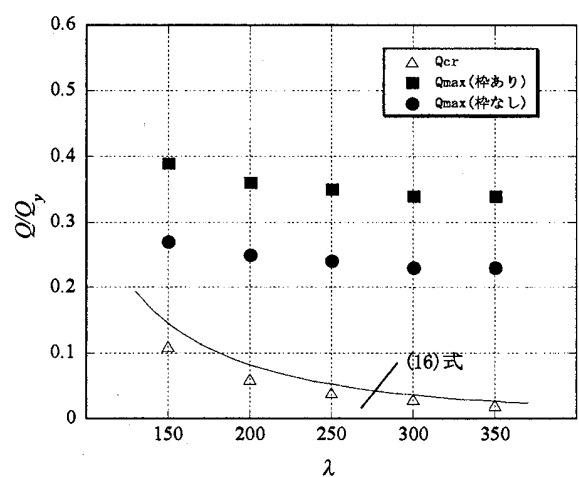

図 10(a) 座屈耐力と座屈後耐力（ $\alpha=0.2, \beta=2.0)$

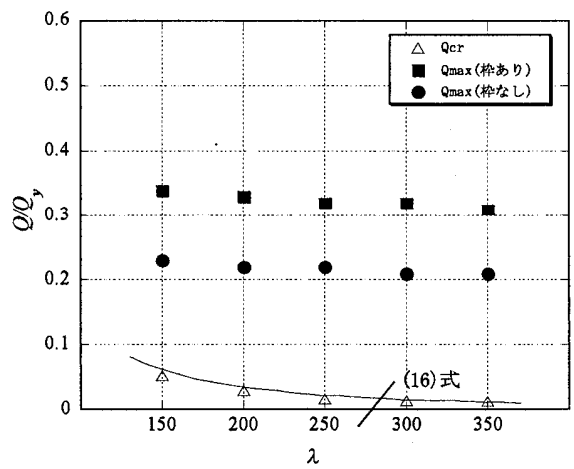

図 10(b) 座屈耐力と座屈後耐力（ $\alpha=0.2, \beta=3.0)$

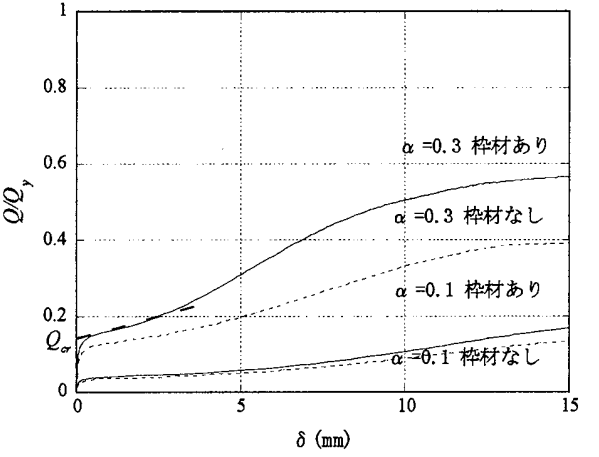

図 9（a）荷重変位（面外方向）関係 $(\beta=2.0)$

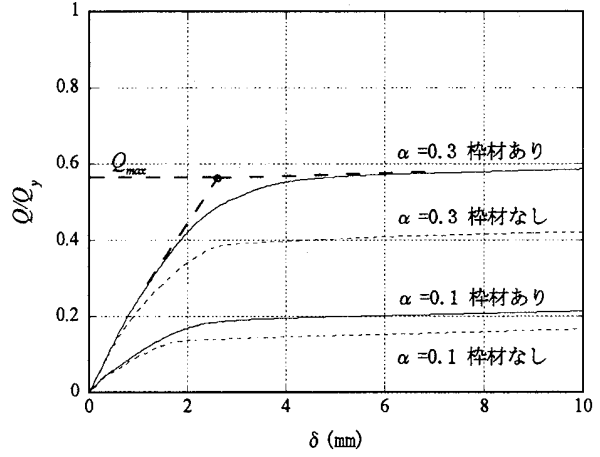

図 9 (b) 荷重変位（面内方向）関係 $(\beta=2.0)$

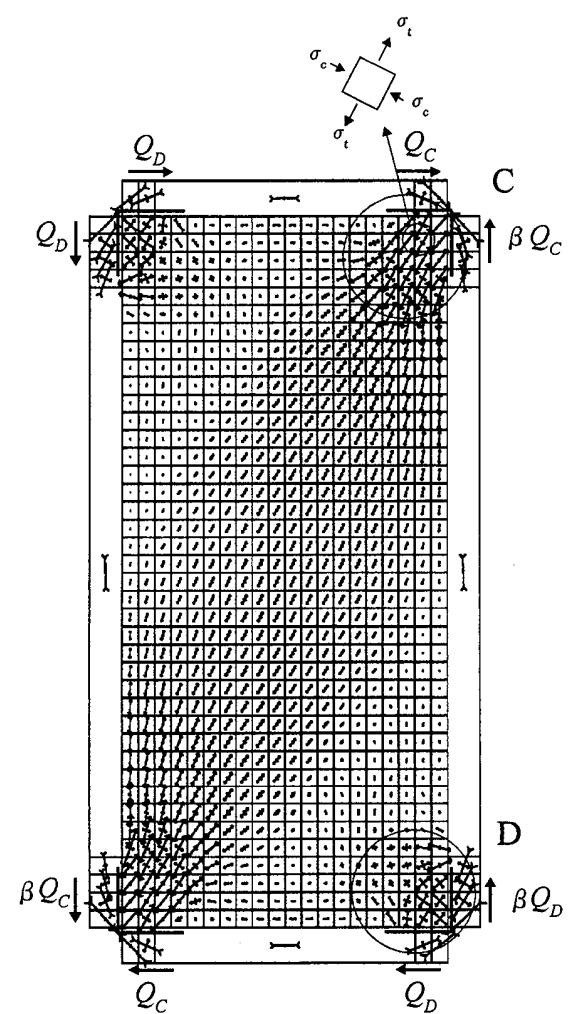

図 12 最大荷重時の応力分布

(枠材あり， $\alpha=0.1, \beta=2.0$ )
$\mathrm{A}$

$\beta Q_{B}$

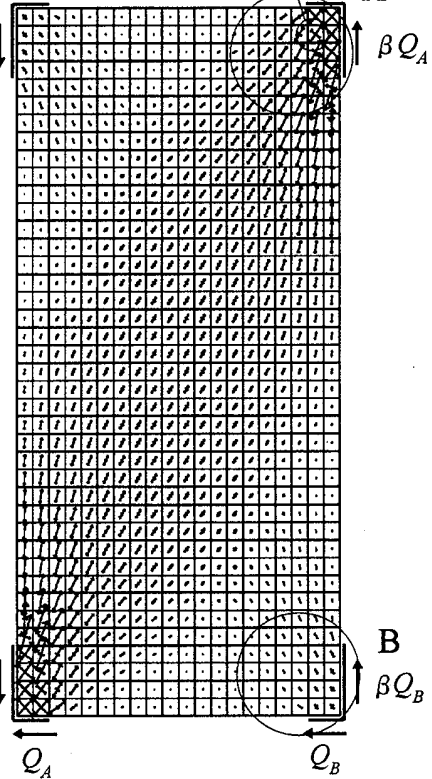

図 11 最大荷重時の応力分布

(枠材なし、 $\alpha=0.1, \beta=2.0$ )
非線形増分解析による座屈耐力は座屈固有值解析で得られた座屈耐力の $80 \sim 100 \%$ となり，初期たわみによる座屈耐力の低下が見られ，文献6） で示されているものと同じ傾向が表れている。座屈後に面外変形を伴い ながらせん断力は增加するが, 支持点付近の鋼板が降伏することにより せん断力一面内変位関係の勾配が急激に低下する。その後もせん断力は 増加していくが,これは材料の降伏後のヤング率を弾性剛性の $1 / 100$ と しているための増加分, 及び大変形領域では対角線方向の引張力が同じ 大きさであってもせん断力に換算する際に大きくなることが原因と考え られる。大変形領域では荷重変位関係はほぼ一定勾配となるため, この 直線の傾きと座屈後の剛性から図 9 (b) に示すように座屈後耐力 $Q_{\max }$ を 決定する。

座屈耐力と座屈後耐力の比較を $\alpha=0.2$ について比較したものを図 10 に示す。幅厚比が大きい鋼板では座屈耐力に対して座屈後耐力の比率は 大きくなる。幅厚比が大きくなると座屈耐力は小さくなるが,座屈後耐 カに対しては幅厚比の影響は小さくなる傾向にある。

枠材なしの場合の最大荷重時の面内応力度分布を図11に示す。これを 見ると,対角線方向から $45^{\circ}$ 方向にかけて斜張力が生じることにより 
座屈後の強度が増大している。支持点付近では, アスペクト比が 2 及 び3の場合でも主応力方向がほぼ $45^{\circ}$ となっている。

枠材ありの場合の最大荷重時の面内応力度分布を図12に示す。これを 見ると,引張力は支持点付近でも対角線方向に発生し, またこれと猃 合う曲げと軸力が枠材に生じているため, 枠材なしの場合と異なり, 引張り方向隅角部では鋼板に圧縮力がほとんど生じていない。

\section{4. 部分支持された鋼板の座届後強度の推定式}

\section{4-1. 伜材の曲げ剛性なしの場合}

前述した座屈耐力の推定式(13)を用い, また図11の最大荷重時の応 力分布の考察から座屈後耐力の推定式を導く。図11の定義により以下 のように考える。

$$
Q_{\max }=Q_{A}+Q_{B}
$$

ここに $Q_{A}, Q_{B}$ は図 11 の 部及びB部の応力度分布に対応するもので ある。 $Q_{A}$ は引張方向の隅角部で $45^{\circ}$ 方向の引張力と直交方向の圧縮力 が釣り合った状態で降伏状態に達し, 座届後耐力に到達していると考 えられる。ここに隅角部での圧縮応力度を $\sigma_{c}$, 引張応力度を $\sigma_{t}$ とす れば以下の式が成り立つ。

$$
\sigma_{c}=-\left(\sigma_{t}\right)
$$

これより,隅角部でのvon-misesの降伏条件より以下の式が成り立つ。

$$
\sigma_{t}=\frac{\sigma_{y}}{\sqrt{3}}
$$

よってこれらの主応力によるせん断耐力 $Q_{A}$ は

$$
Q_{A}=\sigma_{t} \cdot \alpha \cdot t \cdot L=\alpha \cdot Q_{y}
$$

となる。右下, 左上の隅角部付近は斜張力の影響はなく, 座屈時の态 力状態がそのまま維持されていると考えると, $Q_{B}$ は座屈耐力の半分と
なる。したがって最大せん断耐力 $Q_{\text {max }}$ は以下で表わせる。

$$
Q_{\max }=\alpha \cdot Q_{y}+Q_{c r} / 2
$$

$Q_{c r}$ に(13) 式を用い, $Q_{y}$ で無次元化して以下の式となる。

$$
\frac{Q_{\max }}{Q_{y}}=\frac{0.393 \pi^{2} \cdot E}{\sigma_{y} \cdot \lambda^{2}} \cdot \frac{12 \alpha \cdot \beta+(1-2 \alpha) \cdot\left(1+\beta^{2}\right)}{(1-\alpha)^{2} \cdot\left(1+\beta^{2}\right)^{2}}+\alpha
$$

$\beta=1.0$ 場合には前報で示した提案式と同じ式となる。(22)式を数值解 析結果と合わせて $\beta=1.0,2.0,3.0$ それぞれについて図13に示す。解析 值は推定式の $92 \sim 115 \%$ となっており，おおよその一致をみている。

\section{4-2. 枠材の曲げ剛性が大きい場合}

図12の応力分布から座屈後耐力の推定式を導く。Cの部分は板の座 屈後斜張力が対角線方向に生じ,枠材の負担する応力と验り合いなが ら増加し, 引張応力度がほぼ降伏応力度となる。座屈後耐力のC部に 対応するせん断力を $Q_{C}$ とすると，

$$
Q_{c}=\frac{1}{2} Q_{c r}+Q_{T}
$$

となる。 $Q_{T}$ は斜張力によるせん断力增加分, $Q_{c r}$ は (13) 式で与えられる 座屈耐力を示す。斜張力を生じさせるための応力度は座屈耐力との関倸 において決まり, 文献14)を参考に以下の式で表す。

$$
\frac{\sigma_{t}}{\sigma_{y}}=1-\left(\frac{\tau_{c r}}{\tau_{y}}\right)^{2}
$$

鋼板の縁での忘力の釣り合い条件より $\sigma_{t}$ と板の周囲に生じているせん 断応力度 $\tau$ の関係を導くと，

$$
\begin{aligned}
& \frac{\beta \cdot l}{\sqrt{1+\beta^{2}}} \cdot \sigma_{t} \cdot \frac{1}{\sqrt{1+\beta^{2}}}=\tau \cdot l \\
& \tau=\frac{\beta \cdot \sigma_{t}}{1+\beta^{2}}
\end{aligned}
$$

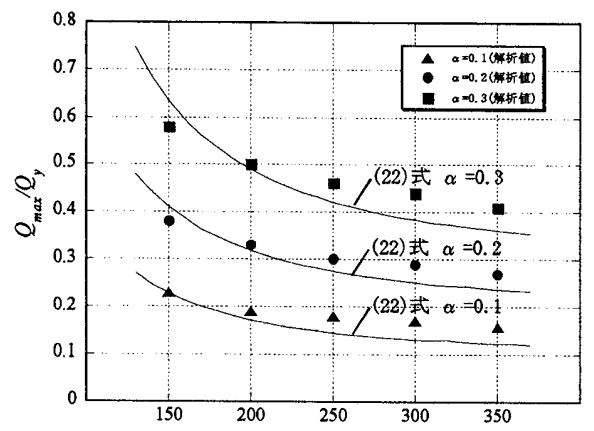

(a) $\beta=1.0$ (伜材なし)

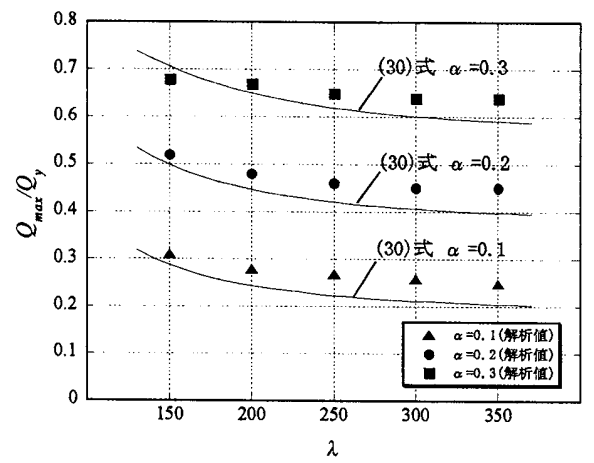

(a) $\beta=1.0$ (枠材あり)

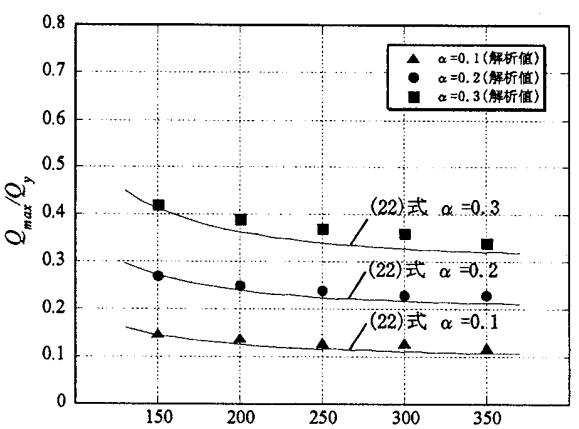

(b) $\beta=2.0$ (枠材なし)

図 13 枠材なし鋼板の座屈後耐力

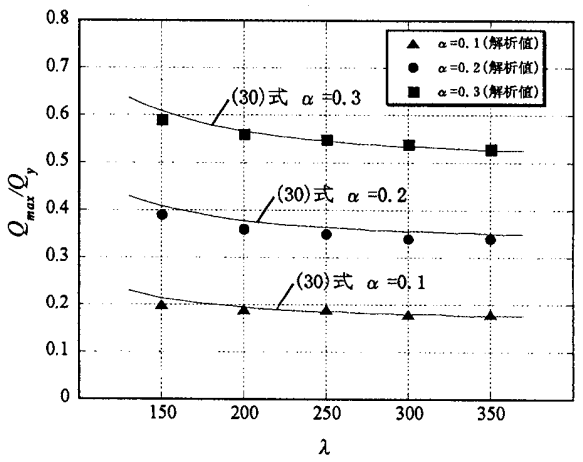

(b) $\beta=2.0$ (枠材あり)

図 14 枠材ありの鎆板の座屈後耐力

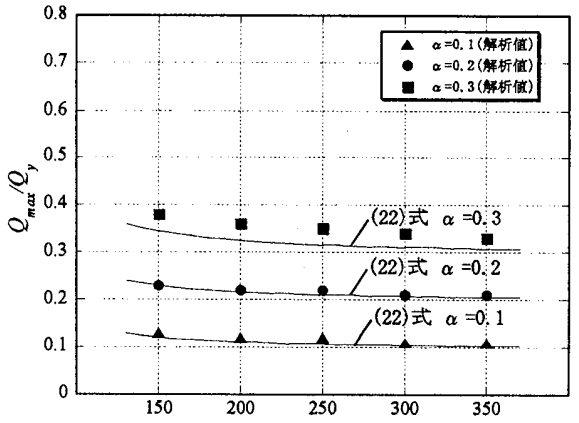

(c) $\beta=3.0$ 人枠材なし)

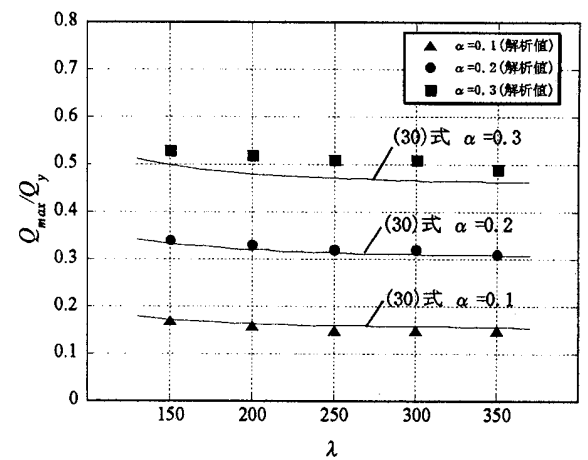

(c) $\beta=3.0$ (枠材あり) 
となるため, $\sigma_{t}$ が対角線方向に生じている時に支持部で負担するせん 断力 $Q_{T}$ は次式となる。

$$
Q_{T}=\left(\frac{\beta}{1+\beta^{2}}\right) \cdot \alpha \cdot t \cdot L \cdot \sigma_{t}
$$

一方, D部では引張応力と圧縮応力が生じて降伏状態となっており, 前 項のA部と同じような傾向となっている。従って, $Q_{D}$ は $(20)$ 式と同じ と考える。

$$
Q_{D}=\alpha \cdot Q_{y}
$$

座屈後耐力は $Q_{C}$ と $Q_{D}$ の和で表されるので

$$
\begin{aligned}
Q_{\max } & =Q_{C}+Q_{D} \\
& =\left\{\frac{1}{2}-\frac{\sqrt{3} \cdot \alpha \cdot \beta}{\left(1+\beta^{2}\right)} \cdot\left(\frac{Q_{c r}}{Q_{y}}\right)\right\} \cdot Q_{c r}+\left(\frac{\sqrt{3} \cdot \beta}{1+\beta^{2}}+1\right) \cdot \alpha \cdot Q_{y}
\end{aligned}
$$

$Q_{c r}$ に(13) 式を用い, $Q_{y}$ で無次元化すると以下の式となる。

$$
\begin{aligned}
\frac{Q_{\max }}{Q_{y}}=\left\{0.393-\frac{1.067 \alpha \cdot \beta}{\left(1+\beta^{2}\right)}\left(\frac{\pi^{2} \cdot E}{\sigma_{y} \cdot \lambda^{2}} \cdot \frac{12 \alpha \cdot \beta-2 \alpha+1}{(1-\alpha)^{2} \cdot\left(1+\beta^{2}\right)}\right)\right\} . \\
\left(\frac{\pi^{2} \cdot E}{\sigma_{y} \cdot \lambda^{2}} \cdot \frac{12 \alpha \cdot \beta-2 \alpha+1}{(1-\alpha)^{2} \cdot\left(1+\beta^{2}\right)}\right)+\left(\frac{\sqrt{3} \cdot \beta}{1+\beta^{2}}+1\right) \cdot \alpha
\end{aligned}
$$

$\beta=1.0$ 場合には前報で示した提案式と同じ式となる。(30)式を数值 解析結果と合わせて図14に示す。解析値は推定式の 96 ～108\%となっ ており,おおよその一致をみている。

\section{5. 枠材剛性が座届後耐力に与える影響 \\ 5-1. 枠材の曲げ剛性と座届後耐力の関係}

枠材が付いた鋼板がせん断力を受ける場合, 座屈後は斜張力により 枠材に曲げモーメント, せん断力, 軸力が生じ,この際に枠材の曲げ剛 性, 曲げ降伏強度が十分に大きいと, 前項で示した座屈後耐力が確保 される。そこで,枠材の曲げ剛性が座屈後耐力に与える影響を検討す る。枠材の曲げ剛性を評価するための基準の剛性として, 斜張力によ り枠材に発生する曲げモーメントに対して必要な曲げ降伏強度を有す る場合の枠材剛性を用い,この基準剛性に対する曲げ剛性比と座屈後 耐力の関係を調べる。

枠材に生じる曲げモーメントは, 図15に示すようなモデル化により 求める。アスペクト比 $\beta$, 支持部分の長さ比を $\alpha$ とすると, 短辺, 長辺 の分布荷重は, 板厚 $t$, 板の斜張力 $\sigma_{t}$ を用いてそれぞれ(31), (32) 式で 表され, 最大曲げモーメントはどちらの枠材も同じ(33)式で表される。

$$
\begin{aligned}
& w_{1}=\frac{\beta \cdot \sigma_{t} \cdot t}{1+\beta^{2}} \\
& w_{2}=\frac{\sigma_{t} \cdot t}{1+\beta^{2}} \\
& M_{\max }=\frac{(2-\alpha)^{2} \cdot \alpha^{2} \cdot \beta^{2}}{8 \cdot\left(1+\beta^{2}\right)} \cdot \sigma_{t} \cdot t \cdot L^{2}
\end{aligned}
$$

枠材の断面2次モーメントを $I_{f}$, 枠材せいを $D_{f}$, 降伏応力度を $\sigma_{y f}$ とす ると, 枠材の降伏曲げモーメントは下式で表される。

$$
M_{a}=\frac{2 I_{f}}{D_{f}} \cdot \sigma_{y f}
$$

$\sigma_{t}$ は (24) 式で表されるが, 幅厚比が大きい鋼板では $\sigma_{y}$ に近似でき る。式を簡略化するため， $\sigma_{t}$ と $\sigma_{y}$ を等しいとすれば, 枠材に生じる曲 げモーメントと許容曲げモーメントとが等しくなる時の断面 2 次モー

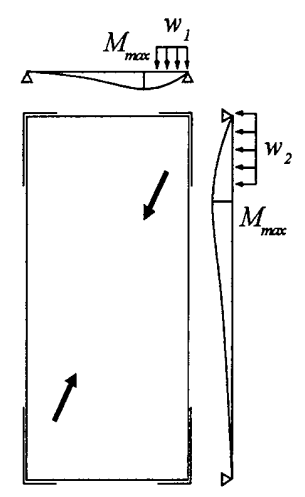

図 15 枠材に生じる応力

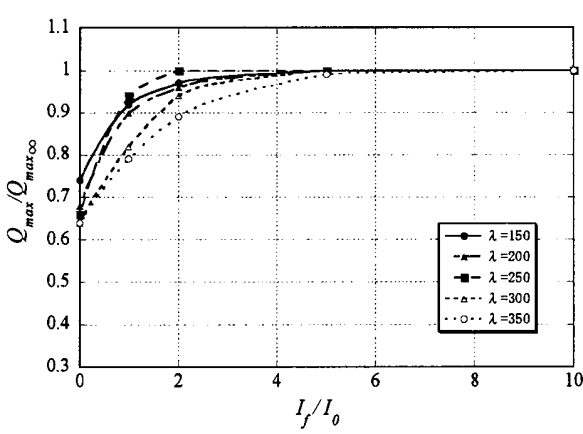

図 16 幅圧比を変化させた場合の染材曲げ 剛性と座屈後耐力 $(\alpha=0.2, \beta=1.0)$
メント $I_{0}$ は(33)，(34)式より下式で表される。

$$
\begin{aligned}
& I_{0}=\frac{(2-\alpha)^{2} \cdot \alpha^{2} \cdot \beta^{2}}{16\left(1+\beta^{2}\right)} \cdot\left(\frac{\sigma_{y}}{\sigma_{y f}}\right) \cdot\left(\frac{D_{f}}{t}\right) \cdot t^{2} \cdot L^{2} \\
& \sigma_{y}: \text { 鋼板の降伏志力度, } \sigma_{y}: \text { 枠材の降伏応力度 }
\end{aligned}
$$

5-2. 枠材剛性をパラメータとした非線形解析

枠材の剛性が座屈後耐力に与える影響を検討するため, 枠材剛性, ア スペクト比, 支持長さ比, 幅厚比をパラメータとして枠付き鋼板の非線 形解析を行い, 座屈後耐力を求めた。鋼板と枠材の降伏応力度は同じと し, 枠材のせいを示す無次元化パラメータ $\left(D_{f} / t\right)$ を10とした。

得られた座屈後耐力を枠材剛性が十分大きい場合の解析值 $\left(Q_{\text {max } \infty}\right)$ で無次元化した結果 (以下耐力比と呼ぶ)を図16〜18に示す。横軸は 無次元化した枠材曲げ剛性であり, 以下枠材曲げ剛性比と呼ぶ。図16 は $\alpha=0.2, \beta=1.0$ の条件下で幅厚比を変化させたものであり,幅厚比 の差による耐力比の違いは比較的小さく, 曲淍性比1.0 2.0の範囲 では耐力比で $10 \%$ 程度となっている。図17は幅厚比 200 について, $\beta$ をそれぞれ $1.0,2.0,3.0$ とした条件下で $\alpha$ を変化させた結果, 図18は 幅厚比200について， $\alpha$ をそれぞれ0.1，0.2,0.3とした条件下で $\beta$ を変 化させた結果を示している。いずれの場合も枠材曲げ剛性比が大きく なると座屈後耐力は大きくなり, 耐力比が1.0に収束していく傾向にあ る。 $\alpha$ の值が小さい場合ほど叹束が早く， $\alpha=0.1$ では枠材曲げ剛性比 が1. 0以上であれば, 完全剛の枠材の場合の座屈後耐力の $90 \%$ 程度が 確保される。同じ曲げ剛性比でも $\alpha$ の違いにより耐力比の違いが生じ るのは, 曲げ強度を基準とした剛性比が同じであっても， $\alpha$ 大゙大くな ると変形の増大の影響がより大きくなるためと考えられる。 $\beta$ の違い による耐力比の差の理由も同様であり,曲げ降伏強度を基準とした枠材 曲げ剛性比だけでは変形に係る剛性の影響を完全に評価できていない ことが分かる。図15に示しているように， $\alpha, \beta$ とも同じ場合には幅 厚比の違いによる耐力比の差は小さい。

木村, 小河はアスペクト比 1 鋼板のせん断座屈後耐力について検討 し, 枠材の曲げ降伏時の曲げ剛性に対しておおよそ16倍以上の剛性を 有する場合には剛性の変化による影響は収束し, 完全張力場が形成され るとしている ${ }^{10)}$ 。本論でも基淮剛性は曲げ降伏強度の剛性を用いてい るが, アスペクト比が 1.0 の場合の数值解析結果では 4 10倍程度の 剛性比で完全剛な枠材が付いた場合の座屈耐力に収束している。鋼板 と枠材の接続が隅角部のみであることにより,曲げ強度を基準とした同 じ剛性比を持つ枠材であっても,曲げによる変形量が小さいことが耐力 比の違いを生じさせていると考えられる。 


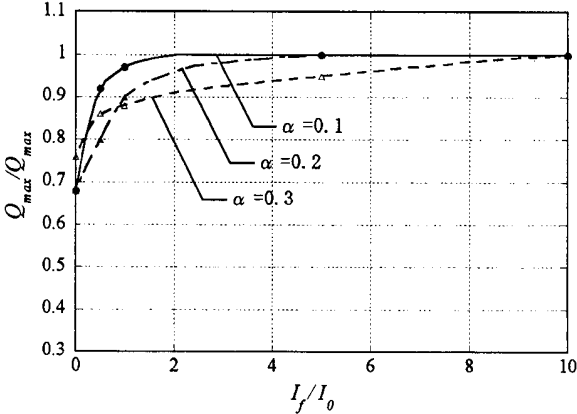

(a) $\beta=1.0$

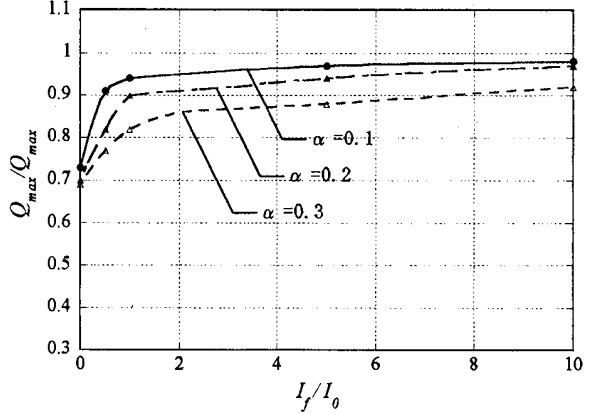

(b) $\beta=2.0$

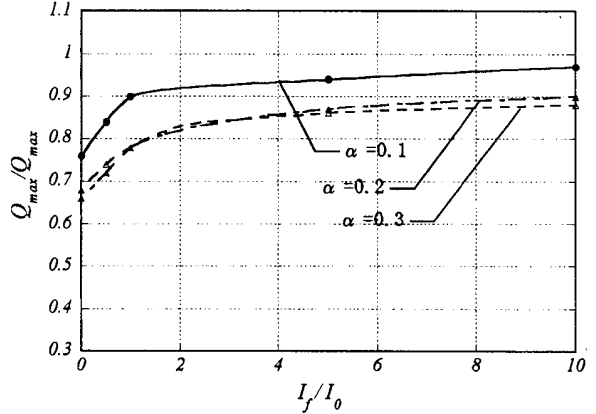

(c) $\beta=3.0$

図 $17 \alpha$ を变化させた場合の枠材曲げ岡性と座屈後耐力

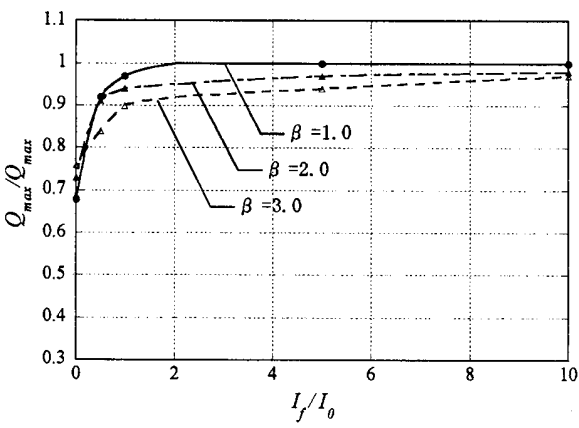

(a) $\alpha=0.1$

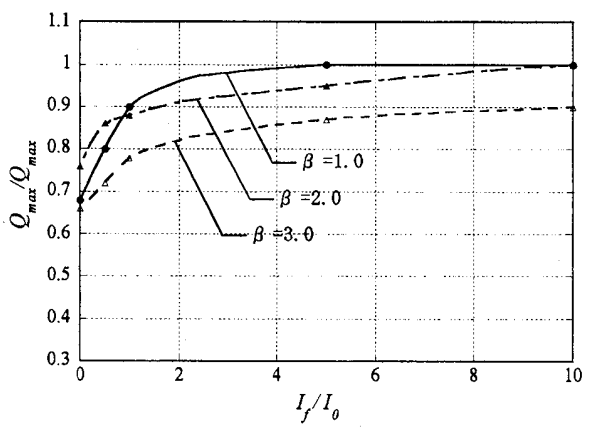

(b) $\alpha=0.2$

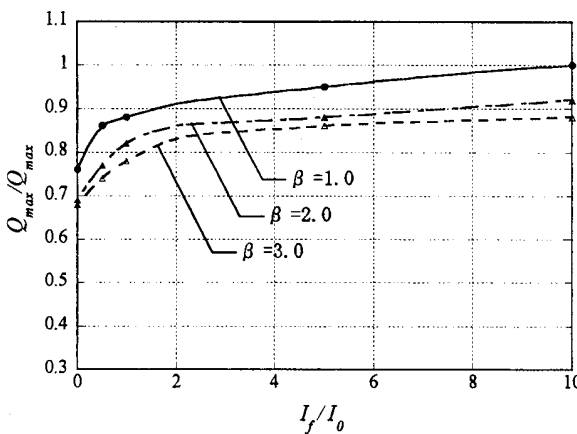

(c) $\alpha=0.3$

図 $18 \quad \beta$ を变化させた場合の枠材曲げ剛性と座屈後耐力

総じて, 今回の検討範囲では, 枠材の曲げ降伏時強度の曲げ㓮性に対 して10倍程度以上の剛性を有していれば, (30) 式で評価される完全 剛な枠材を有する座屈後耐力の $90 \%$ 程度以上の耐力が確保できている と考えられる。

\section{6. 結}

部分支持された幅厚比の大きい鋼板の座屈耐力, 座屈後耐力を,アス ペクト比が1. 0以外の場合についてもブレースモデル及び忘力度分布 に基づいた評価式を提示した。また, 数值解析を行い提案した評価式 との比較を行ない以下のことを確認できた。

1) 部分支持された板の座屈強度は, 支持長さの辺長に対する割合 $\alpha, ア$ スペクト比 $\beta$ をパラメータとして, 適用範囲を $\alpha \leqq 0.3 ， \beta \leqq 3$ とすれ ば, 弾性応力分布から想定したブレースモデルにより，(13)式で概ね評 価できる。

2)枠材の付いた鋼板は, 枠材の曲げ剛性がゼ口の場合でも座屈後の強 度が増大し, 支持部の長さが辺長の $30 \%$ 以下でかつ, 幅厚比が 200 以 上の場合に限定すれば,座屈後耐力は $\alpha, \beta$ を用いて (22)式で概ね推定 できる。

3）枠材の付いた鋼板で枠材の曲げ剛性を無限大とした場合には，支持 部の長さが辺長の $30 \%$ 以下でかつ, 幅厚比が200以上の場合に限定すれ ば, 座屈後耐力は $\alpha, \beta$ を用いて (30) 式でおおむね推定できる。 4) 枠材の曲げ剛性によって座屈後耐力は影響を受け, 今回の検討範囲 では, 曲げ降伏時の曲げ剛性に対して10倍以上の剛性を有している場 合には，(30) 式で評価される完全剛な枠材を有する座屈後耐力の 90 \%程度以上の耐力が確保できる。

上記の結果を基にすれば, 必要な曲げ剛性を持った枠材に部分支持 されたアスペクト比 3.0 以下の銅板耐震壁の座屈後耐力をおおむね推
定できる。ただし，実際の構造物では柱としての枠材には軸力が加わ るが, 本論では軸力が作用したとしても曲げ剛性はほとんど変わらな いという前提で, 枠材曲げ剛性と板の座屈後而力について軸力を考慮 しないで検討を行なった。

\section{参考文献}

1) 金箱温春, 小河利行, 竹内徹, 松原洋介:せん断力を受ける部分支持された薄 鋼板の座屈耐力及び座屈後耐力の評価, 日本建築学会構造系論文集，第 610 号, pp.185-190,2006.12

2) Lee,S.C., Davidson,J.S., Yoo,C.H.: Shear Buckling coefficients of plate girder web panels. Computers and Structures, Vol.59,No.5, pp 789-795,1996

3) Alinia,M.M., Dastfan,M.: Behavior of thin steel plate walls regarding frame members, J. Const. Steel Research,Vol.62,No.7,pp.730-738,2006.

4）見村博明，秋山宏 : 張力場を形成する鋼板耐震壁の復元力特性，日本建築学 会論文報告集，第 260 号, pp.109-114，1977.10

5) Driver,R.G., Kulak,G.L., Elwi AE, Kennedy DJL: Cyclic tests of four-story steel plate shear wall: Journal of Structural Engineering, ASCE ,Vol.124,No.2, pp 112-120,1998

6) Driver,R.G., Kulak,G.L., Elwi AE, Kennedy D.J.L.: FE and simplified models of steel plate shear wall: Journal of Structural Engineering, ASCE ,Vol.124,No.2, pp 121130,1998

7) Elgaaly,M, Caccese,V., Du,C.: Post-buckling behavior of steel plate shear walls under cyclic loads, Journal of Structural Engineering, ASCE,Vol.119,No.2, pp 588-605,1993

8) 山梶隆吉:銅板壁に対する格子型ブレースモデルを用いた数值解析, 日本建築 学会構造系論文集, 第 604 号, pp.159-165,2006.6

9) Lee,S.C., Yoo,C.H.: Strength of plate girder web panels under pure shear. Journal of Structural Engineering, ASCE, Vol.124,No.2, pp 184-194,1998

10)木村衛, 小河利行, 清水英樹 : 薄板の面内せん断挙動について, 日本建築学会 構造系論文集，第 543 号, pp.169-174,2001.5

11) 木村衛, 井上哲郎, 谷口元, 橋村徹, 小松健: 薄板の座屈後耐力, 日本建築学会 構造系論文集，第 545 号，pp.135-140,2001.7

12) 長柱研究委員会 : 弾性座屈要覧, 1969

13)MIDAS Information technology: MIDAS GEN General structural design system, Analysis \& Design, 2002

14) 日本建築学会 : 鑐構造座屈設計指針, 1996 